\title{
Téoros
}

Revue de recherche en tourisme

\section{Tourism 2000 - A global Perspective: Challenges and Opportunities in the Decade Ahead}

\section{Louis J. D'Amore}

Volume 9, numéro 1, mars 1990

Plans et politiques touristiques

URI : https://id.erudit.org/iderudit/1080284ar

DOI : https://doi.org/10.7202/1080284ar

Aller au sommaire du numéro

Éditeur(s)

Université du Québec à Montréal

ISSN

0712-8657 (imprimé)

1923-2705 (numérique)

Découvrir la revue

Citer cet article

D'Amore, L. J. (1990). Tourism 2000 - A global Perspective: Challenges and

Opportunities in the Decade Ahead. Téoros, 9(1), 3-7.

https://doi.org/10.7202/1080284ar d'utilisation que vous pouvez consulter en ligne.

https://apropos.erudit.org/fr/usagers/politique-dutilisation/ 


\section{Tourism 2000 - A global Perspective: Challenges and Opportunities in the Decade Ahead}

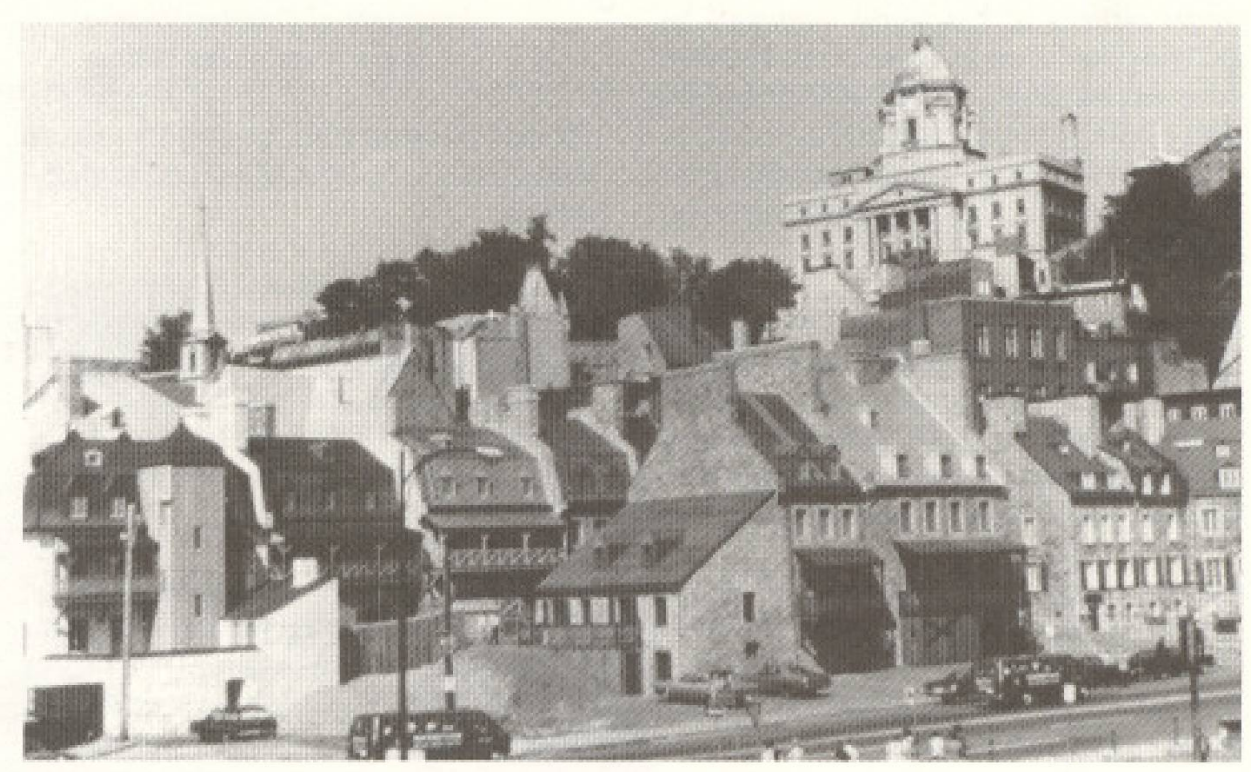

The February 9, 1990 edition of the Montreal Gazette carried a small article announcing the marriage of Susan Eisenhower, grand-daughter of former U.S. President Dwight D. Eisenhower and Roald Sagdeyev, advisor to Soviet President Mikhail Gorbachev,

This relatively unnoticed event is symbolic of the unprecedented political change of the past few months. Eisenhower was President of the U.S. during the height of the Cold War. Now, some forty years later, the walls of communism are crumbling and westernnations have adopted a policy aimed at encouraging the integration of the Soviet Union into the world economy in contrast to the forty year policy of containment.

\section{East-West relations}

The democratization of Eastem Europe and more recently the Soviet Union, combined with the rapid shift in relationships between East and West from policies of confrontation and containment, to one of emerging collaboration, will probably be the single most dynamic force shaping the decade of the 1990's.
It will probably also be the single most influential force shaping the tourism industry in the 1990 's. One of the first rights demanded by East Europeans as they regained control of their governments, was the right to travel. Some one million Czechs, for example, will travel outside the Eastern Bloc this year.

And clearly, travel to Eastern Europe and the Soviet Union is booming. Hungary registered a $40 \%$ increase in visitors in 1989. Poland $20 \%$ and Czechoslovakia about $25 \%$. All hotel rooms in Moscow are already booked for the summer of 1990 . Travel to Eastern Europe and the Soviet Union will continue to increase at approximately $20 \%$ a year, well into the 1990 's.

The travel boom is also opening opportunities for joint ventures. In Czechoslovakia, for example, a dozen joint ventures with foreign companies are planned involving hotel construction, resort development and travel companies. When a Canadian delegation of businessmen led by Prime Minister Mulroney recently visited the Soviet Union, the main news item was a proposal for a $\$ 1$ billion project that "could transform Leningrad into a gleaming tourism showcase". 
The opening of Eastern Europe and the Soviet Union will shape global events into the 21 st Century in other significant ways. For one, it adds a substantial new dimension to the prevailing trend towards the globalization of business (as partly illustrated above). Several international enterprises are establishing a presence in Eastern Europe and the Soviet Union including PEPSICO, Sheraton, Marriott Hotels and FIAT to name a few. By the year 2000 , major airlines of the world may well be ordering Soviet made Tupolev and Ilyushin commercial aircraft. The further expansion of international trade will contribute to continued growth in international business travel, which is already increasing at an impressive rate.

Perhaps most significantly, the warming of East-West relations enables the major nations of the world to focus on other pressing issues - both domestically and on the global agenda - which have not received the attention and allocation of resources warranted.

Foremost among these on the global agenda are the environment, the depletion of natural resources (forests, arable land and oil in particular) and the constantly growing gap between North and South.

Whereas the Cold War diverted trillions of dollars, about one fifth of the world's best scientists, and millions of persons into the world's military -industrial complex within a defense policy framework of "Mutually Assured Destruction"; the Gorbachev era of "glasnost", "perestroika" and "demokratizatsiya" has promise of evolving into an international policy framework of "collaborative global development"

\section{Tourism and environment}

Both East and West now recognize that the main threat to global security is the deteriorating state of the environment - the increasingly polluted air, land and water that sustains all life on earth.

Without correcting problems such as the greenhouse effect, the depleting ozone lazer, polluted oceans, vanishing forests and arable lands - prospects for future economic development will be diminished for all peoples and all nations.

With glasnost has come the realization that areas in Eastern Europe and the Soviet Union are some of the most polluted in the world. The average life span in Poland has actually begun to decline as a result of pollution, and in Czechoslovakia:

"We have spoiled our land, rivers and forests, inherited from our ancestors, and we have today, the worst environment in the whole of Europe. Aduls die here earlier than in the majority of European countries."

\section{Vaclav Havel \\ President of Czechoslovakia New Year's Day Adress}

The environment will be a priority item on both domestic agendas as well as the global agenda.

The tourism industry is directly effected by a deteriorated environment as was experienced in the summer of 1988 along the beaches of the Eastern U.S. coastline and in the summer of 1989 along Italy's Adriatic Coast - both from pollution over which they had no control.

It is quite possible that the proven warming of the earth resulting from the "Greenhouse" effect is the base cause of the lack of snow this year in Europe's ski resorts. And the continued depletion of the ozone lazer will eventually cause vacationers to reconsider a summer holiday at a beach resort for fear of cancer causing ultra violet rays.

Just as the industry has recognized that without peace there is no tourism; we are beginning to appreciate that where we have environmental deterioration, there is no tourism.

\section{Tourism and development: building north-south bridges}

So far we have touched upon East-West relations, the globalization of business and the state of the environment as major global forces shaping the next decade and the destiny of the travel and tourism industry as a natural consequence.

A fourth global force in the 1990 's will be the growing gap between countries of North and South. While futurists in Japan, North America and Europe talk about home entertainment centers, computers in $70 \%$ of homes by the year 2000 , bio-engineering, new materials, robots, advances in communications technology, increased leisure and affluence; prospects for most third world nations are over-populated cities, poverty and associated diseases. Increased poverty is also projected to lead to an increase in crime. Currently, 10 million children a year die from starvation and preventable diseases. In Southern Africa, the spread of AIDS along transportation and migration routes is a major concern.

Here again, improved relations between East and West can lead to cooperation in creation North-South bridges aimed at improved prospects for development in the poor countries of the world.

With enhanced economic development in Third World nations, the tourism industry can benefit first from a range of new destination areas to introduce to a growing travel market, and in time, from a growth in the world population base that has both the desire and the means to travel.

\section{Technology as a creative force}

The fifth obvious choice of a major force shaping the decade of the 1990 's, as touched on above, is the rapid pace of technological development. Consider the technology of transportation. For nearly 7000 years following the invention of the wheel, virtually no technological breakthroughs were made in transportation. Once railroads introduced a mechanized means of transportation, the rate of innovation began to speed up. It took 80 years to move from the age of railways to the age of the automobile, then 40 years to the age of commercial flight and another 20 years to the first voyages in space. Aircraft with speeds of Mach 5 are now on the drawing boards. By the year 2000, high speed trains will connect most major European centers. The U.S. is also beginning the experiment with high speed trains (while we in Canada are unfortunately dismantling VIA Rail). Also envisioned in the next century are mag lev trains which will literally fly a fraction of an inch above their guideways at speeds of $500 \mathrm{~km}$ per hour.

At the other end of the spectrum, progress will be made in solar powered cars as major efforts are made to reduce air polluting emissions from all forms of transportation - particularly the car.

What is significant in the link of warming East-West relations and technology is that much of the world's R\&D and technological innovation in the past forty years has been focused on military applications. Approximately one fifth of the world's scientists have been engaged in research on weapons of destruction. A significant portion of these valuable human resources can 
beshifted to finding solutions to the world's environmental problems; to creating more efficient means of production and distribution, thereby utilizing less energy and less of the world's resources while making more essential goods and services available to more people; finding solutions to the world's waste problems; and meeting new challenges through collaborative international joint ventures such as a manned voyage to Mars.

\section{The role of the tourism industry}

The mid-1980's saw a gradual easing of restrictions in travel to Eastern Europe and the Soviet Union. With that came, first a gradual increase, and more recently, a rapid increase in visitors to Eastern Bloc countries. Clearly, when one to one encounters are made (in Moscow for example) with the "rosy-cheeked" children, all bundled for protection from the $-20^{\circ} \mathrm{C}$ weather; the young people with aspiring careers, many of whom speak a second and third language; the new era bureaucrat and scientist committed to making perestroika work for his/her country; and charming old women in their 70 's, widowed for the past 45 years from World War II; and one begins to sample the history, the rich culture and heritage, the depth of human spirit that is Russia and the Soviet Union; one comes away with a respect and love for these people and a deep hope that the bold initiatives of glasnost, perestroika and a democratic from of government are successful. It is through such experience as travellers, that we can individually come to know the different people and countries of the world, and come to an appreciation of the richness and beauty that is the "Human Family" and the preciousness of the cultural and natural heritage of the global village.

An enlightened tourism industry - that is now the world's largest industry - will recognize this central fact about the benefits of tourism, and will find ways to facilitate travel as an educational experience.

The tourism industry itself, in its own enlightened self interest, will be a leading advocate for an improved environment, and will set standards of excellence regarding environmental and cultural sensitivity in the development of its own facilities.

The tourism industry, combined with our world park systems, can make a contribution to living in harmony with our environment. Tourism makes possible the setting aside and preservation of vast tracts of land as national parks and wilderness areas. More than 3000 protected areas in 120 countries and covering more than 4 million square miles are now preserved in their natural state. Visitors to these areas experience the beauty and majesty of the world's finest natural features and come away with a heightened appreciation of environmental values. In national park townsites such as Banff and Jasper, we have the opportunity for "Man" to be co-creators with nature, bringing the best of human design in juxtaposition with the best of nature.

Kenya provides an excellent example of how the establishment of parks and the development of a tourism industry have evolved. In that country, tourism is now second only to the export of tea and coffee as an earner of foreign exchange.

Since independence, Kenya has enjoyed an internal peace and stability uncommon in the Third World. The Kenyans have astutely avoided military action on their frontiers and have acted as mediators for peace in the region.

Transfrontier parks, or border parks, provide a special category of national parks. These are protected areas located along the boundaries of countries and are increasingly recognized as "Peace Parks". Border parks, on each side of a frontier, offer the benefits of larger, contiguous protected areas, increased cooperation between nations, and improved international understanding.

Tourism can contribute to both the preservation and development of the world's cultural heritage. It provides governments with the rationale for the preservation of historical sites and monuments and the motivation for indigenous groups to preserve unique dimensions of heritage in the form of dance, music and artifacts.

Tourism can also provide both the audience and the economic engine for museums, the performing and visual arts and the restoration of historical areas. Tourism as well, can be a major factor in the re-birth of urban centres.

${ }^{4 B}$ y providing new opportunities and creating new jobs, travel and tourism serve as a catalyst for positive change. Through publicl private partherships and other initiatives, many decaying cinies around th world are being transformed from areas of urban blight to places of culture and beauty.
Warehouses become boutiques, restaurants and hotels; old hospitals and factories are transformed into museums; communities that formerly were shunned create needed jobs for area workers and infuse additional dollars into their economies."

\section{J. Willard Marriot First Global Conference, Tourism - A Vital Force For Peace}

Tourism can also play a vital role in the development of Third World countries. Pope Paul VI once said that "development is the new name for peace". The tourism industry is a human resource-intensive industry. It has the capacity to generate foreign exchange and a high ratio of government revenues as a proportion of total expenditures. As well, it has a capacity for both forward and backward linkages with other sectors of the economy. Properly designed, it can contribute to social and cultural enrichment as well as economic development.

Tourism in the Caribbean, for example, is the major industry of each of the more than 30 states in the region. The tourism industry contributes further to the economy of each state through its linkages to other economic sectors such as fishing, agriculture, and manufacturing. Tourism has, in fact, been the only industry in the Caribbean that has shown steady growth over the past 15 years.

What is also most interesting is that the tourism industry has provided some 30 diverse States of the region - States with different languages (French, English, Dutch, Spanish) and cultures - a basis of collaboration for a common purpose. They have a strong marketing network throughout North America, and now Europe and Asia as well, to promote tourism to their region. This is only possible because they have come together and have combined their marketing resources. They are also increasingly working together in dealing with tourismrelated issues and meeting the challenges of an industry that continues to grow at 6-8 percent a year.

In Egypt, as well, the one Arab country at peace with Israel, tourism now accounts for $30 \%$ of trade in goods and services and is Egypt's single, most important industry.

Tourism is also bringing Egyptians in closer personal contact with their Israeli neigh- 
bours thereby helping to secure a long term peaceful relationship. In 1988, 77000 Israelis visited Egypt as tourists.

The development of tourism through collaborative North-South and public-private sector joint ventures can also help build much needed transportation networks in Third World countries thereby connecting large populations and areas to the world's economic mainstream. Combined with the development of telecommunications, technical assistance efforts would also be facilitated narrowing the North-South information gap and thereby creating a basis for increased investment and trade opportunities. Properly planned transportation and telecommunication infrastructure and economic development projects (including tourism) can also be a means of alleviating over-population, congestion and related problems of Third World megacities.

\section{First Global Conference: Tourism - A Vital Force For Peace}

The First Global Conference: Tourism - A Vital Force For Peace, held in October 1988 in Vancouver sought to identify ways by which the tourism industry could contribute to the peace process by:

- promoting mutual understanding trust and goodwill;

- improving the quality of the environment, both built and natural;

- contributing to the World Conservation Strategy of sustainable development.

The Conference attracted eight hundred participants from 67 countries. More than fifty national and international organizations expressed support for the conference theme and objectives.

The Conference concluded with consensus on a broad range of recommendations related to the environment, planning and sustainabledevelopment of tourism, "Places For Peace", exchange programs, education, and the social, cultural and economic aspects of tourism. The spirit and content of deliberation at the Conference were captured in a communique called the "Columbia Charter" which has been broadly distributed.

\section{International Institute For Peace Through Tourism}

As a result of the Vancouver Conference, the International Institute For Peace

\section{THE COLUMBIA CHARTER}

"The First Global Conference: Tourism - A Vital Force for Peace" ${ }_{\text {, }}$ convened in Vancouver, British Columbia, Canada, Oct. 23-27, 1988,

OBSERVES that tourism is a worldwide social and cultural phenomenon involving people of all nations as hosts and guests;

ASSERTS that tourism is a fundamental human activity involving social, cultural, religious, economic, environmental, educational, and political values and responsibilities;

ACKNOWLEDGES that tourism is growing more rapidly than other economic sectors;

CAUTIONS that the world has reached the critical crossroads in the earth's history demanding responsive strategies that address the political, economic, and environmental problems facing humankind;

DEPLORES developments where tourism can cause turmoil, conflict, or other stresses resulting from the exploitation of the world's natural and cultural resources;

MAINTAINS that the monitoring, protection, preservation, and wise use of the environment and ecological balance is essential to the future of tourism;

CONDEMNS all situations that deny or inhibit in any way the full exercise of human and civil rights as stated in the United Nations charter;

EXPRESSES the urgent reality that peace is an essential precondition for tourism and all other aspects of sustainable human growth and cultural development;

RECOGNIZES that human understanding increases through face-to-face communication and positive interaction between people, especially at the community level;

REMINDS that tourists are both teachers and students whose classroom is the world;

REINFORCES the hope that tourism will nurture conditions through which people can co-exist, share their beliefs, appreciate each other's cultures, and develop friendships;

NOTES that government, academic, and private-sector leaders have identified and supported the potential of tourism as an influencing force for global peace through respect for human dignity, cultural diversity, and the natural environment that supports all life;

SOLEMNLY CALLS upon all nations, governmental bodies, organizations, and individuals to eliminate war, terrorism, and injustice, stop the arms race, free hostages, and shape new policies to guide public and private-sector initiatives to build a world that works for everyone and in which tourism:

- promotes mutual understanding, trust, and goodwill;

- reduces economic inequities;

- develops in an integrated manner with the full participation of local host communities;

- improves the quality of life;

- protects and preserves the environment, both built and natural, and other resources: and

- contributes to the world conservation strategy of sustainable development.

"The First Global Conference: Tourism - A Vital Force for Peace" RESOLVES to implement the conference recommendations and initiatives through responsible action undertaken:

- individually, through our interrelated roles as tourists, hosts, and world citizens, guided by the Credo of the Peaceful Traveler;

- collectively, through the International Institute for Peace Through Tourism and the Columbia Club; and

- through such other strategies required to reach the goal of world peace through tourism. 
CREDO OF THE

PEACEFUL TRAVELER

Grateful for the opportunity to travel and to experience the world and because peace begins with the individual, I affirm my personal responsibility and commitment to:

- Journey with an open mind and gentle heart.

- Accept with grace and gratitude the diversity I encounter.

- Revere and protect the natural environment which sustains all life.

- Appreciate all cultures I discover.

- Respect and thank my hosts for their welcome.

- Offer my hand in friendship to everyone I meet.

- Support travel services that share these views and act upon them and, by my spirit, words and actions.

- Encourage others to travel the world in peace.

The First Global Conference:

Tourism - A Vital Force For Peace

Vancouver, British Columbia, Canada,

October 27, 1988.

Through Tourism was established to work towards the implementation of key conference recommendations.

The Institute is a registered charitable organization located in Montreal.

A current major focus of the Institute is the organization of a Tourism Industry Summit Meeting. Theme of the meeting is Vision 2000.

The Meeting bring together $80-100$ world leaders (by invitation) from key sectors of the travel and tourism industry and related sectors including environment, culture, communications and education.

Its aim is to formulate a set of concrete proposals for East-West and North-South collaboration through which the tourism industry can help contribute to a continu- ation of the peace process at all levels of society.

The President of Iceland, Her Excellency Vigdis Finnbogadottir, who was Honorary Chairman of the Vancouver Conference, has agreed to act as President of the Meeting.

Meetings regarding Vision 2000 have recently been held with senior Soviet officials in Moscow. The soviets expressed their interest in participating fully in all aspects of Vision 2000.

Ambassador Charles E. Cobb, U.S. Ambassador to Iceland, has been collaborating fully in terms of U.S participation. Ambassador Cobb was formerly Undersecretary of Commerce for Travel and Tourism.

Other plans of the Institute include a Second Global Conference to be held in 1992 and a series of Regional Conferences on Tourism - A Vital Force For Peace to be held in Latin America, Asia Pacific, the Mediterranean and Africa.

As well, the Institute will be launching a "Places For Peace" Campaign in the next few months. This is in keeping with a central recommendation of the Vancouver Conference that the tourism industry join with the parks and recreation community, landscape architects, environmental groups and peace groups as catalysts in creating "Places For Peace" throughout the world. From the local community level (Peace Gardens, Peace Memorials, Peace Parks) to the national and international level (Peace Parks, World Heritage Parks and sites, International Friendship trails), "Places For Peace" will serve as places of ceremony and celebration and as crossroads for both domestic and international travellers.

Municipal Peace Parks can serve as the site for Visitor Information Centres which might also serve as "Network Centres" facilitating people-to-people contact for those visitors and local residents desiring such an experience.

Some recent noteworthy examples of Places for Peace are the Toronto Peace Gardens in Nathan Phillip's Square; a Peace Park in Tashkent, a USSR sister city of Seattle, built by 200 volunteers from Seattle working with local residents; and the National Peace Garden in Washington D.C. which has recently been announced and is expected to draw more than 2000 entries in its design competition. The National Peace Garden has already generated interest around the world and has resulted in the building of several peace parks elsewhere in the United States.

Mayor Doré in Montreal, has announced intentions to dedicate a Peace Park, and in Vancouver steps have been taken to dedicate a "Peace Park" at the site of the First Global Conference "Peace Tree Planting Ceremony".

It is noteworthy that the first international peace park, called Waterton-Glacier International Peace Park, was dedicated in 1932 , symbolically uniting Glacier National Park in Montana with Waterton Lakes National Park in Alberta. The park's stated purpose is to permanently commemorate the longexisting relationship of peace and goodwill between the United States and Canada. Forty-four transborder parks now exist, and others are being dedicated.

Persons wishing to learn more about the Institute and its activities are invited to contact the author at:

\section{International Institute For \\ Peace Through Tourism \\ 3680 , rue de la Montagne \\ Montréal (Québec) \\ H3G 2 A8 \\ Tél.: (514) 281-9956 \\ Fax: (514) 848-1099}

